\title{
mpe On the Role of Capital in "Capitalist" and in Labor-Managed Firms
}

\author{
DAVID ELLERMAN \\ University of California, Riverside, 4044 Mount Vernon Ave., Riverside, \\ CA 92507-4804; e-mail: david@ellerman.org
}

Received December 11, 2004; accepted July 13, 2005

\begin{abstract}
This article outlines the "fundamental myth" about the structure of property rights in a capitalist economy, namely the idea that being the residual claimant in a productive opportunity is part of a bundle of property rights known as the "ownership of the firm." Residual claimancy is contractually determined so there is no such "ownership." The fundamental myth exposes a basic fallacy in capital theory that has hitherto escaped attention in the capital theory debates.
\end{abstract}

\section{JEL classification: $P$}

Keywords: property appropriation; capital rights; ownership of the firm; labor-managed firm

This article is divided into two parts. The first part outlines the "fundamental myth" about the structure of property rights in a capitalist economy, namely the idea that being the residual claimant in a productive opportunity is part of a bundle of property rights known variously as "ownership of the firm," "ownership of the means of production," or, to economists, "ownership of the production set (or function)." This argument is based on the simple observation that ownership of a capitalist corporation does not legally entail "ownership of a productive opportunity," since the capital assets of a corporation can be hired out instead of labor's being hired in. That contract reversal shifts residual claimancy in the productive opportunity, but it does not shift ownership of the corporation. Therefore, residual claimancy could not be legally part of the corporate ownership rights. That leaves the dangling question of the role of "capital" in the legal form of the so-called "capitalist corporation" (the ordinary joint stock company). I argue that contrary to much sloppy thinking in the economic literature, capital in the sense of financial or physical capital has no special role in the so-called "capitalist" corporation. This realization plus the fundamental myth add up to the conclusion that the so-called "capitalist" corporation and the socalled "capitalist" system itself are in fact not based on any special rights of capital. That fundamental misconception about capital, due largely to a man who wrote the book titled Kapital, has been accepted both by those who support the misnamed "capitalist" system 
and those who oppose it. Moving beyond that mistaken understanding of the role of capital in "capitalism" is part of moving beyond that system itself to the system Jaroslav Vanek (1970, 1977) called a "labor-managed market economy."

The second part of the article illustrates the fundamental myth in simple formal models and then makes a precise comparison of the structure of rights between a conventional "capitalist" corporation and a democratic or labor-managed firm (LMF). The second part of the article also addresses the problem of the lack of any recoupable rights to the retained earnings in the Yugoslav-style social property firm, a problem known in the academic literature as the "Furubotn-Pejovich horizon problem." The solution realizes an early insight of Jaroslav Vanek that the members' capital rights have to be "external" to and independent of their membership rights in a LMF. The solution is to have a system of what are called "internal capital accounts" for the members, and the solution was "found" at least four times. Vanek arrived at the notion of "external funding" as opposed to "self-financing" for labor-managed firms but then noted that an internal redeemable savings account would be counted as "external"-all of which amounts to an internal capital account. I personally was involved in working out Vanek's idea of "external funding" in the context of the work of the Industrial Cooperative Association, whose acronym (ICA) also coincidentally could stand for "Internal Capital Accounts." The ICA quickly found out that the same idea had already been developed in the Mondragon cooperatives, and it was thereafter presented as the "Mondragon solution" to the problem. The fourth and even older solution was in the system of partner capital accounts to be found in law partnerships and other professional partnerships. That solution was right under our noses all the time, but it took a long time to see it.

\section{The Fundamental Myth}

\section{I.I. The Life-Cycle of a Property Right}

A positive or descriptive theory of property for a private-property market economy should describe how property rights are created or initiated, how they are transferred from party to party, and finally, how property rights are terminated.

Property rights are created in firms and households, and property rights are also terminated by firms and households. In between is the market in which property rights are transferred. The instrument for transferring property rights is the voluntary contract that is fulfilled by the transfer of the de facto possession and control of the property from the old owner to the new owner (usually in exchange for other property going in the opposite direction).

\section{I.2. The Market Mechanism of Appropriation}

While it is well understood that property rights are transferred by voluntary contract, what is the legal means by which property rights are initiated and terminated in a privateproperty market economy? It will be helpful to first establish some notation and terminology. Consider a simplified description of a productive opportunity $Q=f(K, L)$ in which the outputs $Q$ are produced by applying the labor $L$ to the capital services or nonlabor inputs $K$. Many different types of labor and nonlabor inputs could be considered, but that would 


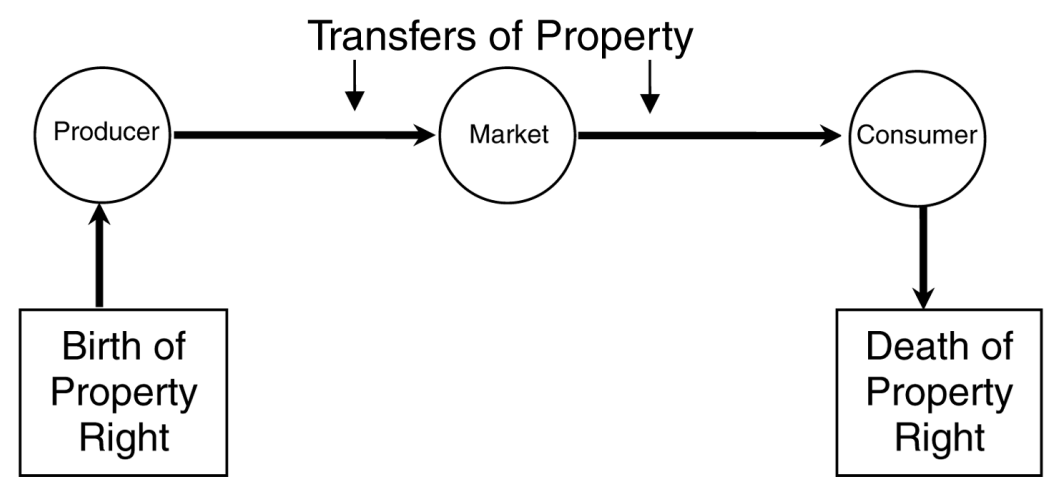

Figure I.

"Life Cycle" of a Property Right

only complicate the notation and would not change the underlying logic. The initiation of a property right is called the "appropriation" of the property right. Symmetrically, the termination of a property right might be called the "expropriation" of the property right, but that word has now been corrupted to mean the forced transfer or "taking" of property by the state. ${ }^{1}$ The use of the word expropriation can be avoided by referring to the "expropriation of the assets $X$ " as the "appropriation of the liabilities $-X$."

In the productive opportunity $Q=f(K, L)$, the property rights to $Q$ are initiated and the property rights to $K$ and $L$ are terminated, so this could be described as the appropriation of the assets $Q$ as well as the appropriation of the liabilities $-K$ and $-L$. It will be useful to adopt a simple vector notation with three components representing outputs, nonlabor inputs, and labor inputs, respectively. Thus, the vector of outputs or assets appropriated in production is $(Q, 0,0)$, and it will be called the "positive product." The vector of liabilities (signifying the used-up inputs) appropriated in production is $(0,-K,-L)$, and it will be called the "negative product." Summing the positive and negative products componentwise gives vector of assets and liabilities appropriated in the productive opportunity $(Q,-K,-L)$, which I will call the "whole product."

$$
\begin{aligned}
\text { Positive Product } & =(\mathrm{Q}, 0,0) \\
+ \text { Negative Product } & =(0,-\mathrm{K},-\mathrm{L}) \\
=\text { Whole Product } & =(\mathrm{Q},-\mathrm{K},-\mathrm{L})
\end{aligned}
$$

The "whole product" is simply a property theoretic name for the production vector familiar to economists in the production-set treatment of production in which the outputs are listed positively and the inputs are listed negatively.

How does a private-property market economy determine who appropriates the whole product? There is a laissez-faire or market mechanism of appropriation. First, consider a nonmarket assignment of liabilities by the legal authorities, as in a trial for property damages

1. "This word [expropriation] primarily denotes a voluntary surrender of rights or claims; the act of divesting oneself of that which was previously claimed as one's own, or renouncing it. In this sense, it is the opposite of 'appropriation.' A meaning has been attached to the term, imported from foreign jurisprudence, which makes it synonymous with the exercise of the power of eminent domain" (Black 1968: 692, entry under "Expropriation").

2. See Menger (1899) for the history of the phrase "whole product," as in "Labour's claim to the whole product." 
in which the defendant is found guilty and held liable for some property that was destroyed. To understand the market mechanism, one must consider who would appropriate the liability $-X$ (i.e., terminate the property right to $X$ ) if the property $X$ is used up, consumed, or otherwise destroyed when the legal authorities do not intervene to have a trial. In that case, the liabilities $-X$ are automatically borne by the last legal owner of $X$. Thus, one could say that in the absence of any state intervention to reassign liabilities, the liabilities $-X$ for used-up or destroyed property $X$ is "laissez-faire appropriated" by the last legal owner of $X$. Furthermore, that same legal party who bore the liabilities would have the defensible legal claim (in the absence of any reassignment of the liabilities) to any new property that might be created in the process of using up the old property.

\section{Market Mechanism of Appropriation}

Let the liabilities for the used-up inputs lay where they have fallen (i.e., in the hands of the last owner of the inputs), and then let that party have the claim on any produced outputs.

It should be noted that this mechanism of appropriation only works for produced outputs, as opposed, for example, to gifts of nature.

In terms of our example, the last legal owner of the nonlabor inputs $K$ and labor inputs $L$ would laissez-faire appropriate the negative product $(0,-K,-L)$. In the absence of any state intervention to reassign those liabilities, that same party would have the defensible legal claim on the positive product $(Q, 0,0)$. Putting the two products together, one has the market mechanism for the appropriation of the whole product $(Q,-K,-L)$. The legal party who appropriates the whole product of a productive opportunity will be called the "firm" (with respect to that opportunity). Since that party would pay for the liabilities $-K$ and $-L$ and receive the revenue from the outputs $Q$, the whole product appropriator is also called the residual claimant.

\section{I.3. The "Fundamental Myth" about Property Rights}

The "market mechanism of appropriation" might all seem like a fancy way to restate the obvious, but it has quite strong implications. For instance, it shows that for a legal party to be the "firm" with respect to a given productive opportunity, it is sufficient for the party to be the last legal owner of all the inputs used up in the production process. Then that party has the defensible legal claim on the outputs that emerge in production, so that party would appropriate the whole product. Since it is the fact-pattern of the input contracts (e.g., whether capital hires labor or labor hires capital) that determines who is the last legal owner of the used-up inputs, the identity of the firm ("firmhood") is contractually determined. There is no need for the legal party to additionally buy or own the production function or production set. There is no such thing as the "ownership" of a production function or production set in a private-property market economy. It is not by the ownership of a production set that production or whole-product vectors are assigned to legal parties but by the market mechanism of appropriation.

The idea that there is a property right (variously called "ownership of the firm," "ownership of the production function," "ownership of the productive opportunity," and so forth) that determines which party legally appropriates the whole product of a productive opportunity is such a pervasive and important idea that it will be called the "fundamental myth" about property rights. If it is thought that the whole product is already owned by the 
owner of the firm, then the entire question of appropriation (initiation and termination of property rights) in production is not even formulated. That is indeed the usual case in the conventional economics literature. ${ }^{3}$

While this fundamental myth appears in many guises in neoclassical economics (not to mention in ordinary consciousness), one also finds in the same literature the alternative view that residual claimancy is a legal consequence of the structure of contracts (who hires what or whom). In marginal productivity theory, one can find the "suppose labor hires capital" discourse, and in the Austrian or neo-Austrian literature (e.g., Alchian and Demsetz 1972), one can find arguments that the contracts should be written one way rather than another for various reasons (e.g., entrepreneurship or transaction and information costs). In fact, the typical situation is one in which contractually determined residual claimancy is assumed in the discussion of "free markets" (who would deny that labor is legally permitted to hire capital?), but then the same writers will automatically switch over to an "ownership of the production function" or "ownership of the firm" view in capital theory or corporate finance theory (see below).

\section{4. "Ownership of a Firm" and Ownership of a Corporation}

What are the origins of the fundamental myth that firmhood or residual claimancy is established by an ownership right ("ownership of the firm") rather than by the contractual status of being the last legal owner of all the inputs to production? Perhaps the most common origin is an abstract misinterpretation of the ownership of a corporation as the "ownership of the firm." But it might be noted that economists use the notion of "ownership of the firm" in more general contexts independent of corporations. In an abstract model, entrepreneurs are "bidding for ownership of the firms" (Hirshleifer 1970: 124) and become the "owners of the productive opportunity" (125). A proprietor may sell "the rights to the transformation function" or "his rights to the venture" (Fama and Jensen 1996: 341) to another proprietor. The entrepreneur is the "owner of a production function" (Haavelmo 1960: 210), and even Robinson Crusoe "owns the firm" (Varian 1984: 225).

The most common or "standard" origin of the "ownership of a firm" notion is to (mis)interpret the ownership of a corporation that is currently undertaking a production opportunity $Q=f(K, L)$ — by virtue of its contractual position—as being "ownership" of the productive opportunity. But this interpretation can be easily defeated by conceptually changing the contractual position of the corporation without changing its ownership. For instance, if the capital services' $K$ were to be hired out rather than the labor services' $L$ being hired in, then the "firm" in the sense of whole-product appropriator would shift, but the ownership of the corporation would be in the same hands. The role of the corporation would shift from being the firm (with respect to that opportunity) to being an input supplier to the firm. ${ }^{4}$

3. For example, in Putterman and Kroszner's anthology (1996) on the "economic" nature of the firm, none of the papers pose the question of appropriation in their treatment of the firm. The question of appropriation in the firm is similarly ignored in the "economics of property rights" (e.g., Furubotn and Pejovich 1974) and in the so-called "property rights approach" to the firm (e.g., Hart and Moore 1990; Hart 1995).

4. This conceptual analysis of the structure of ownership rights is distinct from the empirical question of whether or not labor has the social power and inclination to reverse the contracts. 


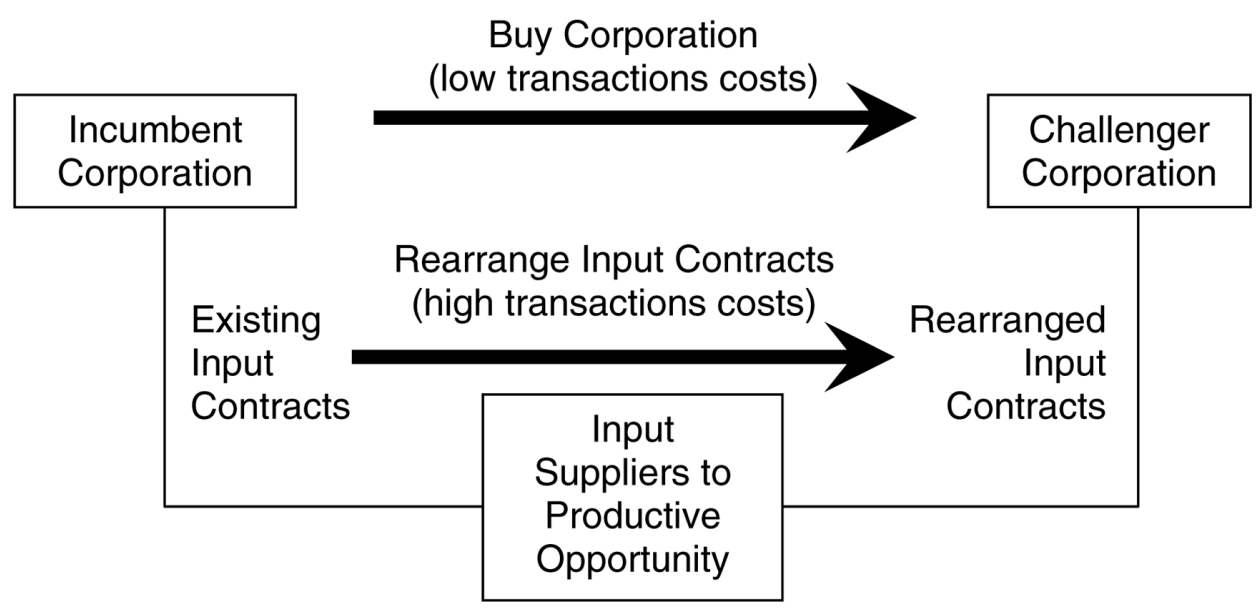

Figure 2.

Two Ways to Take Over a Productive Opportunity and Thus "Become the Firm"

This argument might be better understood by considering a productive opportunity both outside and inside a corporate form. Consider a simplified process in which the labor $L$ is applied using the services $K$ of a widget-maker machine to produce the widgets $Q$ during each time period. If the machine is owned by an individual, it is clear that the person could hire in the labor $L$ and produce $Q$-or could hire out the services $K$ to another party. The pattern of contracts determines whether the individual operates as the firm (with respect to that opportunity) or as an input supplier to the firm. Now suppose that the individual incorporates a company and issues all the stock to herself in return for the machine. This legal repackaging changes nothing in the market logic of the argument that separated capital ownership from residual claimancy. The corporation (rather than the individual) would own the widget-maker machine, and depending on the direction of the hiring contracts, may or may not appropriate the whole product of the productive opportunity using the widget maker. The process of incorporation does not miraculously transubstantiate the ownership of a capital asset into the ownership of the whole-product vectors that might be produced using the capital asset.

In realistic markets, there are likely to be large transaction costs to rearranging the input contracts. The incumbent corporate residual claimant has sizable first-mover advantages, so that any challenging party would have to incur such high transaction costs to redirect the input contracts that it might be just as cheap or cheaper to simply buy the corporation and thereby take over the residual claimant's position in the existing pattern of input contracts. These transaction cost barriers create the image that the existing corporate residual claimant "owns" the production opportunity.

One of the advantages of idealized frictionless models in economics, as in physics, is that they show the basic logic of the system without distractions. In a world without transaction costs and social power relations, the input contracts could be costlessly rearranged to switch residual claimancy from one party to another without changing the ownership of a corporation from one party to another. That shows the contractual determination of residual claimancy in a private-property market economy. 
The transaction cost and social power barriers to rearranging contracts in real-world markets create the illusion of a property right such as the everyday notion of "ownership of the firm." Transaction cost barriers and power relations are only that; they are not property rights. For instance, as transaction costs change, it might become more feasible to acquire residual claimancy by rearranging input contracts rather than by purchasing the corporation. This would not violate the corporation's "ownership of the production set," since it had no such property right in the first place. ${ }^{5}$

\subsection{The Fundamental Myth in Capital Theory and Corporate Finance Theory}

The fundamental myth has an important role in many parts of conventional economics. I will only touch on its role in capital theory and corporate finance theory, as that has some relevance for our current topic.

One of the simplest forms of the fundamental myth is the assumption that the bundle of rights that constitute ownership of an asset includes "a right of ownership-over-theasset's-products, or jus fruendi" (Montias 1976: 116), or simply, "the right to the products of the asset" (Putterman 1996: 361). The ambiguous jus fruendi expressions are innocuous if the "products of the asset" such as the aforementioned widget-maker asset are just the services $K$. But the expressions involve the fundamental myth if the "products of the asset" include the product $Q$. That latter version of the fundamental myth pervades orthodox capital theory and is then carried over to corporate finance theory (viewing a corporation as a complex machine).

Suppose that the widget-maker machine yields $K$ units of machine services per year for $n$ years and then has no scrap value. The asset owner has the property right to the stream of capital services $K$, or in vectorial terms $(0, K, 0)$, each year for $n$ years. But if the asset owner also has the contractual role of the firm or residual claimant in that production opportunity for the $n$ years, that party will additionally appropriate the whole products $(Q,-K,-L)$, which sum for the stream of net ownership vectors $(Q, 0,-L)$ for $n$ years (the first row plus the second row equals the bottom row in the following Table 1).

Orthodox capital theory then discounts the value of the net vectors $(Q, 0,-L)$-bottom row in Table 1-back to the present to arrive as the "capitalized value of the asset" as if the right to the whole products (second row) had been part of the ownership of the assets.

5. While the lay misinterpretation of ownership of a corporation might be understandable in a world of significant transactions costs, it is less clear why economists should still be wedded to the lay concept in the "standard model" of general equilibrium in an idealized world free of transaction costs. For instance, the fabled attempt by Arrow and Debreu (1954) to show the existence of a competitive equilibrium with positive "pure profits which are distributed to the owners of the firm" (Arrow 1971: 70) is flawed in theory because they incorrectly assume there is the ownership of production sets in a private-property market economy. To pinpoint the error in their mathematical formulation, the problem is not in assuming corporate ownership, that is, that the $i$ th consumer owns "a contractual claim to the share $a_{i j}$ of the profit of the $j$ th production unit" (Arrow and Debreu 1954: 270) in which "production unit" is a corporation. The error is the assumption that for "each production unit $j$, there is a set $Y_{j}$ of possible production plans" (267) and that this corporation is the only party allowed to bid on the inputs for that production opportunity. The ownership of a corporation is misinterpreted as the ownership of a production set even in the idealized frictionless model in which a challenger corporation could bid slightly higher for the inputs (and get lower but still positive profits) to take over a production opportunity and thus defeat the purported "competitive equilibrium" with positive pure profits. 


\section{Table I}

Parsing the Property Vectors

\begin{tabular}{|c|c|c|c|c|}
\hline & Year 1 & Year 2 & . . & Year $n$ \\
\hline Property vector owned by asset owner & $(0, K, 0)$ & $(0, K, 0)$ & . & $(0, K, 0)$ \\
\hline $\begin{array}{l}\text { Property vector appropriated by last } \\
\text { owner of inputs (residual claimant) }\end{array}$ & $+(Q,-K,-L)$ & $+(Q,-K,-L)$ & . . & $+(Q,-K,-L)$ \\
\hline $\begin{array}{l}\text { Net property vector accruing to asset } \\
\text { owner who is also the residual claimant }\end{array}$ & $=(Q, 0,-L)$ & $=(Q, 0,-L)$ & . . & $=(Q, 0,-L)$ \\
\hline
\end{tabular}

When a man buys an investment or capital asset, he purchases the right to the series of prospective returns, which he expects to obtain from selling its output, after deducting the running expenses of obtaining that output, during the life of the asset. (Keynes 1936)

But the appropriation of the whole products is contingent on a certain contractual fact pattern, and it is not a violation of the ownership rights of the asset owner to have the asset hired out instead of labor's being hired in. Thus, the value of the whole products ("profits") might or might not go to the asset owner, depending on the future pattern of the input contracts. The so-called "capitalized value of the asset" is actually the value of the asset (discounted value of the $[0, K, 0]$ stream in the first row) plus the discounted value of the stream of whole products (discounted value of the $[Q,-K,-L]$ stream in the second row) where the latter may or may not accrue to the asset owner. That imputation fallacy is the fundamental myth in capital theory.

To illustrate how the recognition of contractually determined residual claimancy and the fundamental myth can be side by side in an economist's work, we might take the example of one of the most careful thinkers, Paul Samuelson. Samuelson freely indulges in the "switch the roles of labor and land" (1976: 543) discourse in his treatment of labor in marginal productivity theory both in his principles text and in his more advanced writings. But when he comes to capital goods, then marginal analysis is left behind. Capital goods are claimed to have a "net productivity" (1976: 600) because Samuelson assumes that the owner of the capital good is also the residual claimant. The net return "to undertake" a capital project "by tying up your money in it" is interpreted as the "net productivity" of the capital good itself (1976: 601). By imputing part of the return accruing to the contractual role (i.e., being the one to undertake the project) to the capital good itself, Samuelson makes the standard capital theoretic use of the fundamental myth. ${ }^{6}$

There is no legal necessity that the owner of the machine be the residual claimant (with respect to the widget-making process), and the same holds when the owner is a corporation. Yet, corporate finance theory carries over the same capital-theoretic fallacy of interpreting the whole product as part of corporate ownership. For instance, the discounted cash flow method of valuation routinely assigns to the corporation the present value of the net

6. Samuelson is at least careful to call it the "net" productivity of capital. Most writers define the same notion and then crudely refer to it as the "marginal" productivity of capital or "marginal" efficiency of investment. The issue here is the structure of the rights involved. That structure is not changed by assuming a perfectly competitive long-run equilibrium in which profits are zero. As Hegel pointed out, the question of the color of cows is not usefully addressed by assuming a night in which "all cows are gray." 
cash flows (e.g., from $[Q, 0,-L]$ on the bottom row of Table 1) from production rather than the present value of the cash flows from the services of the underlying corporate assets (e.g., from $[0, K, 0]$ on the top row).

There, in valuing any specific machine, we discount at the market rate of interest the stream of cash receipts generated by the machine, plus any scrap or terminal value of the machine, and minus the stream of cash outlays for direct labor, materials, repairs, and capital additions. The same approach, of course, can also be applied to the firm as a whole, which may be thought of in this context as simply a large, composite machine. (Miller and Modigliani 1961)

But to plausibly count the future whole products as part of the present property rights of the corporation, all the future input contracts would have to be made in favor of the corporation at the present time. Moreover, since contracts are generally not enforceable until one side performs, the corporation would have to have paid all future input contracts at the present time. Only then could the corporation have a plausible claim on the future whole products. Since those conditions would hardly be fulfilled, the usual discounted cash flow method of valuation does not value the property rights "of the corporation." It values the underlying assets of the corporation plus the additional value that would accrue to the corporation if it had the contractual role of residual claimant throughout the projected future time periods. We return to this theme with a more formal model in part 2 below.

\section{I.6. The Role of Capital in the So-Called "Capitalist" Corporation}

We have analyzed in some detail the fundamental myth in several of its hydra-headed manifestations. We have used the trivial fact that the capital assets of a corporation can be hired out just as labor can be hired in to make the point that the "ownership of the corporation" does not include the "ownership of the productive opportunity" (represented by a production function or set), which might involve the capital assets of a corporation. Residual claimancy in the productive opportunity depends on the direction of the hiring contracts, and there is no legal necessity for the contracts to be made in the corporation's favor. The corporation may find that like many natural persons, it can only remuneratively use its assets by renting them out. This simple argument cuts, as it were, the legal link between a corporation and a production function.

Now, we consider a different question about the nature of the conventional joint stock company - the so-called "capitalist" corporation. Does physical or financial capital (the capital on the asset side of the corporate balance sheet) play any special role vis-à-vis the corporate ownership rights? For instance, labor certainly plays a special role in the labormanaged firm with the assignment of the membership rights to those who work in the firm. Is there some similar structure for the shareholders as "capital suppliers" in the conventional joint stock company?

Some researchers have tried to set up a neat symmetry between labor-managed firms and "capital-managed firms" (KMFs) in which the latter are identified with the conventional joint stock company, the "capitalist" corporation (e.g., Dow 1993, 2003). The membership rights in the KMFs supposedly go to the "capital suppliers" just as they go to the labor suppliers in the LMFs. 
Similar ideas seem firmly planted in the popular and academic consciousness. Somehow, the corporate ownership rights are based on the ownership of capital goods. ${ }^{7}$ The rights of the shareholder are supposedly based on the shareholder's supply or investment of capital in the company.

Perhaps the most explicit development of this theme is Henry Hansmann's (1990, 1996) treatment of the conventional joint stock corporation (which Hansmann somewhat question-beggingly calls the "investor-owned" corporation). To understand Hansmann's approach, we need to look at the general structure of cooperatives that assign the "ownership rights" to the "patrons." The patrons are different in different types of cooperatives. In a consumer co-op, the members patronize the co-op by buying there. In a marketing co-op, the members sell their outputs through the cooperative. In a worker cooperative, the members patronize the cooperative by working there. Similarly for farmer supply cooperatives, housing cooperatives, and credit cooperatives (credit unions and mutual savings banks). Hansmann's theory is that the conventional corporation is essentially a "capital cooperative" or "lenders" cooperative" (1996: 14).

The members of the capital cooperative each lend the firm a given sum of money, which the firm uses to purchase the equipment and other assets it needs to operate (say, to manufacture widgets - or cheese). The firm pays the members a fixed interest rate on their loans, set low enough so that there is a reasonable likelihood that the firm will have net earnings after paying this interest and all other expenses. The firm's net earnings are then distributed pro rata among its members according to the amount they lent, with the distributions taking place currently, as dividends, or on liquidation. Similarly, voting rights are apportioned among members in proportion to the amount they have lent to the firm. To supplement the capital that it obtains from its members, the firm may borrow money from lenders who are not members but who simply receive a fixed rate of interest (which may be different from the fixed rate paid to members) without sharing in profits or control. (Hansmann 1996: 14)

Hansmann goes on to argue that this is "precisely the structure that underlies the typical business corporation" (14) in which we interpret the lender-members as the shareholders and their fixed interest rate as zero.

Hansmann is clear that shareholders who bought shares on the secondary market are not direct suppliers of capital, but for the sake of argument we can join him in a generous interpretation of a secondary shareholder as being an indirect "capital supplier." Also, one should note that shareholders who buy higher valued new shares have the same share rights as those who bought them cheaply. There is no contradiction in having a fully leveraged corporate start-up. Some paternalistic jurisdictions require a significant legal minimum of paid-in capital ("to protect creditors"), but most modern statutes have at most a symbolic minimum of paid-in capital.

The real problem in the thesis is that shares can be obtained for any of the reasons that any property is transferred-such as in return for labor, nondurable inputs, managerial or technological know-how, and political goodwill or as a bequest or gift. To attract a prized employee, a company might issue new shares as a "signing bonus." Workers might receive new shares in lieu of or in addition to cash wages. Or one could receive shares for any consideration

7. For instance, the "rights of authority at the firm level are defined by the ownership of assets, tangible (machines or money) or intangible (goodwill or reputation)" (Holmstrom and Tirole 1989: 123). 
whatever. And one can receive shares in return for no consideration, that is, as a gift or inherited property. These shareholders have the same rights as the shareholders who are directly or indirectly capital suppliers, so it is hard to sustain the "capital cooperative" hypothesis without generalizing the definition of capital to include any consideration whatsoever, or indeed, no consideration.

The real point is that shares are freely transferable property. Perhaps the defense of the thesis of the joint stock corporation as a KMF or "capital cooperative" boils down to an intellectual game of naming whatever might be received in return for newly issued shares as a variety of "capital." Labor and managerial know-how are "human capital," nondurable inputs are "short-term capital," technological know-how is "intellectual capital," political goodwill is "political capital," and even giving shares away for no consideration is reaping "reputational capital" or "goodwill capital." I suppose getting shares in a bequest is the return to one's supply of "familial capital."

What is the alternative hypothesis? Start with the idea of a cooperative in which the shares are assigned to those who have a certain patronage role, as in a worker, consumer, housing, or marketing cooperative. Then, take the limit as the patronage role goes to zero. In the limit, the shares would become free-floating with no patronage prerequisite necessary to qualify one for ownership. With the patronage requirement null, one could sell the shares for whatever they would fetch or give them away as a gift. The conventional joint stock corporation is not a "capital cooperative" or capital-patronage cooperative; it is the null-patronage cooperative. The shares in the so-called "capitalist" corporation are simply free-floating property rights. The joint stock company is not like a cooperative in which the "patronage" is supplying capital; it is a limiting case of no patronage.

There is another way to verify this analysis. Perform the gedanken experiment of starting with whatever idea one has of a KMF or capital cooperative. Then, arrive at an institutional design of a company that takes the limit as the capital-supplying qualifying role of the shareholder goes to zero. The profit and control rights attached to shares require no qualification on the part of a shareholder; they are freely transferable property rights. One then arrives at the notion of a universal corporation whose shares are free-floating property unattached to any role of supplying labor or capital or patronizing the company in any way or being related to the company in any other way (than as "shareholder"). A little more thought reveals that this is indeed what the joint stock company has become. This, in part, accounts for the flexibility and staying power of this legal form.

This approach shows the unique limiting role, and hence, universality of the so-called "capitalist" corporation. If it did not exist, it would be soon reinvented, because if possible, the patronage role would be soon diminished to zero. For instance, retiring cooperative members looking for as wide a market as possible for their shares want no patronage restrictions on the buyers, so there is pressure to convert the firm into an accommodating universal legal form. Indeed, many small start-up companies function almost like "cooperatives" until the founders want to move on and want to be able to sell their shares to the highest bidder-with no functional role required.

\section{I.7. Taking the "Capital" Out of "Capitalism"}

Contrary to the fundamental myth, "capitalism" is not based on any special "divine rights of capital." The point of capitalism is not that capital has more rights than people but 
that people have no more rights than capital. Both capital and people are equally rentable. All input services, the actions of persons like the services of things, are legally transferable. Capital can hire labor or labor can hire capital. It is the question of who hires what or whom, namely the direction of the hiring contract, that determines who is the firm (residual claimant). Thus, the ill-named "capitalist" system has a certain universality based on the free marketability of all input services. ${ }^{8}$ Thus, anyone, by becoming the hiring party, the nexus of the hiring contracts, can become the firm. That nexus could itself be an artificial legal person, the conventional corporation, which also has the universality of being property freely marketable to any and all buyers or even gifted to any and all beneficiaries regardless of any functional role they may or may not play.

Labor management, laborism, workplace democracy, or economic democracy is thus not symmetrical to capitalism. The "capitalist" system was misnamed by the author of Kapital, and the misconception has persisted ever since. Capitalism recognizes a universality based on a legal symmetry between persons and things; both are rentable. Laborism is not legally symmetrical between persons and things. It is based on abolishing the contract for renting human beings, just as the contract for lifetime rental, the voluntary self-enslavement contract, is already abolished. ${ }^{9}$ Thus, laborism exhibits an asymmetrical bias in favor of persons as opposed to things; things may be rented, but persons may not be rented in a laborist system. The characteristic institution of so-called "capitalism" is not the private ownership of the means of production but the voluntary contract for the renting of human beings, the employer-employee contract. ${ }^{10}$ We shall note later that the property-rights structure of a labor-managed or democratic firm can be derived from the old principle that people should have a natural property right in the fruits of their labor (which is also just the propertytheoretic version of the juridical principle of imputing legal responsibility to the de facto responsible party). With the "capital" out of "capitalism" and economic democracy founded on the principle of people getting the fruits of their labor, the tables are turned on the role of private property in the great debate over the form of the economic system.

If "wage" were used to denote exclusively the rental payment for labor under the employment contract (not the advances made to members in a democratic firm), then the capitalist system would be the "wage system" or the "wage labor system." Indeed, that was

8. Since the abolition of even a voluntary slavery contract after the Civil War, the "capitalist" system only has universality and symmetry in the markets for flows of input services-not for the underlying stocks. As Samuelson put it, "Since slavery was abolished, human earning power is forbidden by law to be capitalized. A man is not even free to sell himself: he must rent himself at a wage" (Samuelson 1976: 52 [his italics]). Incidentally, this market imperfection is routinely ignored in the "fundamental efficiency theorem" that a competitive equilibrium is allocatively efficient. But as one careful and forthright economist put it, "Now it is time to state the conditions under which private property and free contract will lead to an optimal allocation of resources. . . . The institution of private property and free contract as we know it is modified to permit individuals to sell or mortgage their persons in return for present and/or future benefits" (Christ 1975: 334).

9. See Ellerman $(1992,1995)$ for extensive discussion and history of the self-rental and self-sale contracts.

10. To illustrate the power of the fundamental myth, I should mention my own first writings on the topic (Ellerman 1972, 1973), which naively assumed that the rights to the product were part of the "ownership of the means of production" and then inveighed against those "private property rights." Only later did I understand how the market mechanism of appropriation, in effect, assigns the whole product to a contractual role. Since the rentability of things is not at question, this points out the key role of the employment contract (the rentability of persons) as the legal foundation of the "capitalist" system-which would better be called the "employment system" or the "wage labor system." 
the name used in America when the "wage system" was juxtaposed to the "cooperative commonwealth"11 before the importation of Marxian emphasis on "private ownership of the means of production."

\section{I.8. Intellectual Background to the Fundamental Myth}

Since the fundamental myth can be exposed by a simple contract reversal argument, how has it been such a stable part of orthodoxy? Marx shares responsibility by having given his imprimatur, but the idea goes back to older notions of land ownership. In feudal times, the governance of people living on land was taken as an attribute of the ownership of that land: "ownership blends with lordship, rulership, sovereignty in the vague medieval dominium" (Maitland 1960: 174). The landlord was lord of the land. As von Gierke put it, "Rulership and Ownership were blent" (1958: 88). Marx carried over that idea to his analysis of capital in capitalism. The command over the production process was taken as part of the bundle of capital ownership rights.

It is not because he is a leader of industry that a man is a capitalist; on the contrary, he is a leader of industry because he is a capitalist. The leadership of industry is an attribute of capital, just as in feudal times the functions of general and judge were attributes of landed property. (Marx [1867] 1967: 332)

Marx was simply wrong; he bought the fundamental myth concerning the structure of legal rights. ${ }^{12}$ The employer's legal right of discretionary control over the actions of the workers is legally based on the employment contract. Such "rulership" is not blended with or part of the ownership of capital assets. Asset ownership by itself only gives the owner the legal right to make the worker a trespasser.

Marx's "ownership of the means of production," indeed Marx's notion of "capital," involves the mythical "ownership of the firm." By "capital," Marx did not simply mean financial or physical capital goods; he meant those goods used by wage labor with private ownership of the means of production. Otherwise, "capital" becomes just the "means of labor." In short,

Marx's "capital" = "means of labor" + "contractual role of being the firm."

If one wishes to use the word capital in that Marxian sense, then one gives up being able to talk about the "ownership of capital," since there is no "ownership" of a contractual role. But Marx continued to talk about "capital" (in the sense that includes residual claimancy) as being owned in a linguistic move that might be called a "semantic straddle."

There is a similar ambiguity in the common language notion of "owning a factory." There is the ownership of factory buildings (or corporations with such assets), but there is no "ownership" of the going-concern aspect of operating a factory, as that is a contractual role in a market economy. By using the same phrase, owning a factory, to straddle both

11. See, for example, Grob (1969), Goodwyn (1978), or Lasch (1991).

12. The topic here is the symmetry of legal rights between capital and labor services in the employment system. The topic is not the obvious consequences of the system in the huge inequalities of wealth and social influence between capital and labor. 
meanings, one could seem to have an argument that the contractual role of operating a factory was "owned." For instance, when it is argued to many economists today that "owning the factory" (in the sense of operating it) is a contractual role, not an extra owned property right, a typical response is, "Yes, but it is that role which I call the 'ownership' role." After thus redefining ownership as a contractual role, they then straddle back to the old meaning and talk of it as a property right. Those are some of the thought patterns in Marxist thought and in neoclassical economics that allow the fundamental myth to limp on.

\section{Rights Structures in "Capitalist" and Labor-Managed Firms}

\section{I. The Capitalized Value of a "Capital Asset"}

We start with the simple case of a capital asset (previously considered) to parse the property rights, and thus the value rights, between what is owned now and what needs to be appropriated by the contractually determined residual claimant now and in the future. This conceptually includes the example of a corporation in which the so-called "value of the corporation" can be parsed between what parts are actually owned now and what parts represent property to be appropriated in the future. Then, we move over to the labormanaged firm and consider what happens to the property rights of what is actually owned now. Those were the property rights treated as social property in the Yugoslav-style selfmanaged firm but that are captured as private property rights in the labor-managed firm with internal capital accounts.

Let us, for the sake of simplicity, suppose that the capital asset yields the stream of services $K$ in perpetuity. Each year, the labor $L$ uses up those services to produce the product $Q$. If the owner of the capital asset were also the residual claimant in perpetuity, then each year he would receive the same net property vector $(Q, 0,-L)$ that can be parsed as in Table 1 into the actually owned capital rights $(0, \mathrm{~K}, 0)$ and the whole product $(Q,-K,-L)$ appropriated each year by virtue of the presumed contractual role of being the residual claimant.

These property theoretic arguments can be translated into value terms by multiplying through by prices. Let $P, R$, and $W$ be the unit prices of output, capital services (rental rate), and labor services, and let $r$ be the interest rate-all assumed constant for the sake of simplicity. The discounted present value of a constant income stream is obtained by dividing the constant "annuity" by the interest rate $r$, so the present value of the stream of rentals $R K$ from the capital asset is $R K / r$, which is the economic value of the asset (ignoring for the moment any maintenance and depreciation). The value of whole product is the pure or economic profit $\pi=P Q-R K-W L$. The present value of the net property stream accruing to the combined asset owner and residual claimant is what is called the

$$
\text { Capitalized Value "of the Asset" }=(P Q-W L) / r=R K / r+\pi / r=\text { Asset value }+ \text { Goodwill. }
$$

The capitalized value of the future pure profits is usually called the "goodwill" (the difference between the capitalized value of the whole net income stream and the value of the underlying economic assets). Including the capitalized profits or goodwill in what is called the "capitalized value of the asset" in effect assigns the future to-be-appropriated whole products to the current owner of the capital asset - the capital theory version of the fundamental myth. 
The same conceptual analysis is applied in corporate finance theory to a corporation as a capital asset. In Miller and Modigliani's article on the dividend irrelevance principle (1961), they gave four equivalent formulas for corporate valuation starting with the capitalized stream of dividends formula. The (net) asset value + goodwill formula is equivalent to the other four formulas (see Ellerman [1982] for a proof), but it is the only one of the formulas that allows one to parse the underlying property rights into the actual assets and liabilities of the corporation plus the assets and liabilities to be appropriated in the future.

In the context of a corporation, the net asset value is the current economic value of the company's actual assets and liabilities. In addition, corporate finance theory assumes that the company perpetually has the contractual role of being the residual claimant to additionally appropriate the whole product in each time period. The present value of the perfectly tangible but future to-be-appropriated whole products is the goodwill. Thus, the net assets + goodwill formula allows us to parse the property rights into what is actually owned and what may or may not be owned depending on future contractual roles.

An analogy might clarify the point. Consider a beggar who has money put into his cup by passing pedestrians. When does the beggar acquire ownership of these gifts? Perhaps it is when the money passes into his possession by being put into the cup. But in any case, one could not say that he owned today the money that might be deposited in his cup in the future. Yet, one could imagine an entrepreneurial beggar as "securitizing his future income stream" by selling shares in his future take for, say, the next day (we assume the necessary financial accounting and monitoring system in place to prevent cheating). Thus, the beggar might sell for a certain amount today a 20 percent share of his take tomorrow. We have already ascertained that the beggar does not own today the money he may be gifted tomorrow. What property right has the buyer of the 20 percent acquired today? The buyer only has a right to 20 percent of tomorrow's take whatever that may be. The buyer might estimate it to be five dollars, but if it turned out to be only one dollar, then the buyer was not "robbed" of any property right. Lamentations about the groundless practice of booking the "purchased goodwill" as an "asset" on the buyer's balance sheet would be of little avail.

Corporate valuation theory is in an analogous position with respect to the future whole products and their value, the future profits-with "goodwill" as the discounted value. Buyers of corporate shares might assume that future contracts will be written in the same way, but no property right backs up that expectation - and the unjustified practice of booking "purchased goodwill" as an "asset" (i.e., a property right) changes nothing. ${ }^{13}$ Yet, the corporate shareholder does have a property right, implicitly or explicitly, to the future rental stream from the corporate assets. Thus, when conventional corporate finance theory capitalizes both the rentals and the whole product values into the "value of the corporation," it is incurring the fallacy of the fundamental myth by presenting the value of the future whole products as part of the current value of the corporation.

13. Some accountants have correctly argued that "purchased goodwill" is only an "anticipation," not a property right, and thus, that it should be booked as a charge to equity to be replaced if and when the future whole products are appropriated, that is, when the future earnings are realized. "The amount assigned to purchased goodwill represents a disbursement of existing resources, or of proceeds of stock issued to effect the business combination, in anticipation of future earnings. The expenditure should be accounted for as a reduction of stockholders' equity" (Catlett and Olson 1968: 106). 


\subsection{Parsing the Corporate Ownership Rights}

We are now in a position to parse the rights involved in the "ownership" of a conventional corporation so that we may consider how the rights might be differently structured in a labor-managed firm. We simplify down to the essentials: the voting rights (to elect the board, to select the management, and to vote on any other questions put to the stockholders) and the economic value rights that can now be parsed into the net asset value and the (economic) profit rights. The net asset value is for the current time, but the voting and profit rights need to be broken down into the current rights and future rights after the current time period. Thus, we have the following taxonomy:

\section{Corporate Ownership Rights}

A. Voting Rights
A.1. Current Voting Rights

A.2. Future Voting Rights

B. Value Rights

B.1. Profit Rights
B.1.a. Current Profit Rights
B.1.b. Future Profit Rights

B.2. Net Asset Value

In the previous discussion of the fundamental myth, it was crucial to distinguish between the ways in which vague phrases such as ownership of the firm are used. If by firm we mean a legal entity such as a corporation, then there is indeed the ownership of a (conventional) corporation, but there is no property right or other legal obligation that a corporation would be the residual claimant in a productive opportunity-say, in such an opportunity using a capital asset owned by the corporation. In the "capitalist" economy, capital may be hired out just as people may be hired in. If by firm in the phrase ownership of the firm we mean the party that is the residual claimant in a productive opportunity, then that sort of "firmhood" is not something that can be "owned." It is a contractual role in a "capitalist" economy.

In the above taxonomy, it is the corporate ownership rights that are being listed, not the nonexistent rights to "ownership" of a productive opportunity, production function, production set, transformation locus, or any of the other abstract technological notions that economists all too often confuse with legal and institutional forms. Thus, the (B.1.) profit rights of the corporation are indeed owned by the shareholders, but they will be nil if the asset is rented out instead of labor's being hired in to undertake production. The activity of the corporation maintains the value of asset, but it does not participate in the productive opportunity in which $L$ uses up $K$ to produce $Q$. Thus, the profit rights (B.1.) of the corporation are there but add no value to the net asset rights (B.2.).

In the conventional joint stock company, these corporate ownership rights (voting + value rights) are property rights represented by the common voting shares that may be owned and freely transferred as any other property rights.

\subsection{The Structure of Rights in a Labor-Managed Firm}

We focus on the rights structure in a type of labor-managed firm that I will just call a "democratic firm." The corporate ownership rights are not only rebundled but are assigned 
on a different basis. The rights structure is derived from first principles that have been detailed elsewhere (see Ellerman 1992). The voting rights are assigned on the basis of the democratic principle of self-government. The people working in the firm are the only people under the management of the firm's managers, so by the democratic principle, the voting rights to elect those managers (perhaps indirectly through board election) should be assigned to the people working in the firm. Note that this assignment to those people is based on the assumption that those people are playing a certain functional role, that is, working in the firm. They do not "own" the voting rights as property rights to be held or sold independently of their functional role. It is the same with political rights in a democracy. We call rights assigned to a functional role personal rights (but one can use whatever label so long as the concept is clear).

The workers in the firm change, so the assignment of the voting rights will change with the workforce. The future workers, like the future citizens in a political democracy, do not have to buy their voting rights from the present holders. Hence the separation of the (A) Voting Rights into the (A.1.) Current Voting Rights and (A.2.) Future Voting Rights. It is the (A.1.) Current Voting Rights that are part of the bundle of Membership Rights attached to the functional role of currently working in the democratic firm. The (A.2.) Future Voting Rights would be assigned when the future becomes the present.

The second normative principle (here called the responsibility principle) is just the standard jurisprudential norm of assigning to people the legal responsibility for the results of their deliberate and intentional actions. The intentional actions $L$ of the people working in the firm produce the outputs $Q$ by using up the capital services $K$. In vector terms, the product of the human activity $L$ is $(Q,-K, 0)$. Since the so-called "capitalist" system hypostatizes this human activity $L$ as a service "owned" by the workers and "used up" in production, we can parse the product of this human activity as

$$
\text { Labor Product }=(Q,-K, 0)=(0,0, L)+(Q,-K,-L)=\text { Labor Services }+ \text { Whole Product. }
$$

Since the workers already "own" their labor $(0,0, L)$, by imputing labor's product to the workers, the responsibility principle would additionally be imputing the whole product to the workers. That is precisely the (B.1.a.) Current Profit Rights. Thus, those rights would also be in the bundle of membership rights assigned as personal rights to the functional role of working in the firm (where "working in the firm" in the current time period means producing the current labor product). As one might expect, the (B.1.b) Future Profits Rights represent the future whole products that would be assigned to the future workers who produce them.

Thus, on the basis of the first principles of democracy and responsibility, we have accounted for all the rights except the (B.2.) Net Asset Value rights. In terms of the pointin-time versus time-period distinction (e.g., balance sheet versus income statement), the net asset value is a current value relating to a point in time, while votes are cast and profits are earned in each time period. There is no reason to assume that the net asset value is supplied by or produced by the current workers. Current workers will, to be sure, use up the capital services $K$ derived from the asset with value $C$, and that is why they are held legally responsible for the liabilities $-K$, but we are now concerned with the rights to the net asset value. This value represents property rights accumulated by production and exchange in the past, so the claims on the value by past and present members would be determined by the history of past transactions. 


\section{Table 2}

Parsing the Rights in "Capitalist" and Democratic Corporations

\begin{tabular}{lll}
\hline Rights Structure & "Capitalist" Corporation & Democratic Corporation \\
\hline $\begin{array}{l}\text { Current membership rights } \\
\text { (A.1. + B.1.a.) }\end{array}$ & Owned as property rights & Assigned as personal rights \\
Future membership rights & by shareholders & to the current workers \\
(A.2. + B.1.b) & Owned as property rights & Assigned as personal rights \\
Net Asset Value rights & by shareholders & to the future workers \\
(B.2.) & Owned as property rights & Owned as property rights \\
& by shareholders & by the current workers \\
\hline
\end{tabular}

The system of internal capital accounts is quite simply the means of keeping track of that history so that the net asset value is in whole or part owed in varying amounts to current and past members. They contributed to that value through any membership fees paid in and through any profits (or losses) retained in the firm rather than being paid out (or assessed, in the case of losses). These claims could be thought of as a form of "internal" debt (like a shareholder's loan) subordinate to all other (external) debts. Indeed, the internal capital accounts should be interest bearing. The balance is a property right, not a personal right. One test to distinguish personal and property rights is inheritability. If a member dies, the voting and profit rights (like political voting rights) do not pass to the person's estate, but the internal capital account balance would be a debt of the company to the estate of the deceased member.

Thus, we have seen how all the corporate ownership rights are rebundled and assigned in a democratic firm. The current voting and profit rights are bundled together as the membership rights attached to the functional role of working in the firm (in practical terms, usually after a certain probationary period), so the future voting and profit rights would go to future members, and the remaining net asset value rights are captured in the system of internal capital accounts held by the current members. The accounts of past members would be closed and elevated into an external debt of the company to the ex-member. The rights structure in the so-called "capitalist corporation," and the democratic firm can now be compared point-by-point in Table 2 .

\subsection{Origins of Internal Capital Accounts}

There has been some controversy about how the net asset value should be treated. One widespread socialist belief was that the net asset value must be collectively owned as in the English common-ownership firms or the former Yugoslav self-managed firms-a holdover from the mistaken view that "capitalism" was based on the "private ownership of the means of production." To analyze this view, it must first be recalled that the voting and profit rights have been partitioned away from the rights to the net asset value. The phrase "private ownership of the means of production" usually does include specifically the rights to control and reap the profits from the means of production. But those rights have been restructured as personal rights assigned to labor in the democratic firm. Hence, the remaining right to the net asset value does not include the control and profit rights traditionally associated with "equity capital" or with the "ownership of the means of production."

Let us suppose that it is still argued that any private claim (for example, by past workers) on the net asset value of a democratic firm would be "appropriating social property to 
private uses." Now some net asset value might come from a historical endowment that should not be appropriated by whoever happen to be the current workers. Very well, that endowment could be captured in a separate (bearing interest to reflect its scarcity) "collective account" (as in the Mondragon cooperatives). But what about that portion of the net asset value that comes from retained earnings in the past or paid-in membership fees?

In a democratic firm, the past workers could, in theory, have used their voting and profit rights to pay out all the net earnings instead of retaining any in the firm, assuming they could cover any financing needs by borrowing. Suppose they retained some earnings to finance a machine. Why should those workers lose their claim on that value-except as they use up the machine? Why should the fruits of their labor suddenly become "social property" simply because they choose to reinvest it in their company?

Consider the following gedanken experiment in a "social property" LMF. Instead of retaining the earnings to finance a machine, suppose the workers paid out the earnings as bonuses, deposited them all in one savings bank, and then took out a loan from the bank to finance the machine using the deposits as collateral. Then the workers would not lose the value of those earnings, since that value is represented in the balance in their savings accounts in the bank. And the enterprise still gets to finance the machine. Since the finance was raised by a loan, there was no private claim on the social equity capital of the enterprise. The loan capital is capital hired by labor; it gets only interest with no votes and no share of the profits. This hired capital satisfied Jaroslav Vanek's (1975) idea of "external" finance as opposed to self-finance.

Now, we come to the point of the thought experiment. How is it different in principle if we simply leave the bank out and move the workers' savings accounts into the firm itself? Instead of going through the whole circuitous loop of paying out the earnings, depositing them in the bank's savings accounts, and then borrowing the money back-suppose the firm directly retains the earnings, credits the workers' savings accounts in the firm, and buys the machine. The capital balance represented in the savings accounts is essentially loan capital. It is hired by labor, it receives interest, and it has no votes or profit shares. This was the conceptual route followed by the ICA to develop the idea of internal capital accounts (before learning about the Mondragon accounts), and Jaroslav Vanek seems to have followed a similar route, since he explicitly noted that his notion of "external" funding would include such capital accounts.

Into our concept of external funding we also include redeemable savings deposits of members, bearing a market rate of return paid, as to other creditors, prior to the distribution of labor incomes. To the extent that our analysis comes out in favor of external funding, it also favors this type of individualized funding by members. (Vanek 1975: 445)

Before Vanek's and ICA's development of the internal capital account concept, they were developed in the Mondragon cooperatives, and before that in the capital accounts of legal and other professional partnerships.

\subsection{Are There Property Rights Deficiencies in Democratic Firms?}

As pointed out by Furubotn and Pejovich $(1970,1974)$, the social-property LMFs such as the Yugoslav self-managed firms suffered from a property-rights deficiency since the 
current workers have no recoupable claim on their retained earnings. This means that they would, in effect, be sacrificing the portion of any investment financed by such retained earnings that was not completely depreciated during the horizon of their membership in the firm. This Furubotn-Pejovich horizon problem is now a solved problem. The solution is the system of internal capital accounts as used, for example, in professional partnerships and in democratic firms such as the Mondragon-type worker cooperatives (see Ellerman 1986). ${ }^{14}$

But do democratic firms suffer from additional property-rights deficiencies? The internal capital accounts take care of the net asset value rights (B.2.). But the membership (voting and profit) rights are property rights in a conventional joint stock company while they are "only" personal rights in a democratic firm.

To evaluate this difference, we must again be keenly aware of the distinction between rights over corporate activity and rights over the productive activity (e.g., $L$ 's using up $K$ to produce $Q$ ). The conventional shareholder does have a current property right to future corporate economic profits (if any), but there are no present property rights to the whole product of future productive opportunities. If the corporation makes the right contracts in the future, then it will be the residual claimant for the whole product produced during those time periods. The more likely that is, the more someone may be willing to pay now for the corporate shares. Yet, as in any "buying goodwill" contract, there is no actual present property right that is being purchased. If the asset disappears without recompense, the shareholders can go to court to try to recover, since the corporation owned that asset. But if the future contracts do not work out as hoped, so that the future whole products (whose present value was the "goodwill") disappear without recompense, the shareholders who paid extra for the "goodwill" have no legal recourse.

In spite of these caveats, the member of the democratic firm does not even have the possibility within the structure of the firm to hire the future workers and appropriate their whole products. ${ }^{15}$ The future membership rights would go to the future workers, not the current workers. Indeed, all democratic polities suffer from similar defects. The current generation of citizens does not have property rights to the future citizenship rights, which can be sold since those future rights will attach as personal rights to the future citizens.

This "defect" of democracy accounts for one of the pressures to overturn the democratic structure and cash in on alienating the future rights. In an environment that not only

14. This is still little understood by both the critics and defenders of workplace democracy. It is understandable that the orthodox defenders of the system of renting human beings would treat any minor technical problem in some democratic firms as an intrinsic, inherent, and inescapably fatal flaw. But it is less understandable that some proponents of workplace democracy have not learned which problems are now solved. For instance, in Spain, there are SAL (Sociedad Anonima Laboral) firms, some literally across the street from Mondragon cooperatives, that typically use a "membership share" that carries both the membership rights and the net asset rights. As the initial generation of worker-owners nears retirement, they would at least like to recoup the value of their paid-in capital and retained earnings (i.e., their share of the net asset value), but there is considerable "moral pressure" on them to sell the shares to the younger nonmember employees at whatever the latter can afford. In short, they have yet to learn the basic separation of the personal membership rights from the property rights to the fruits of past labor (e.g., membership fees and retained earnings accounted for in internal capital accounts) so that each type of right can be treated appropriately. A similar system of membership shares was used in the American plywood "co-ops," but those "co-ops" represent a spent historical example, while the SALs are a vigorous current movement that, in this regard, seem to have learned little from the past failures of cooperatives.

15. This market imperfection in a democratic firm of not being able to voluntarily rent other people is over and above the current defect or market imperfection of not being able to voluntarily buy other people or to sell oneself. 
allows but welcomes such "conversions," we would expect democratic firms to be somewhat like mules that do not reproduce well across generations. As the founding generation nears retirement, it faces a fundamental choice. It can retire ("like George Washington"), leaving the democratic structure intact and receiving the net asset value, or it can convert the democratic firm into a conventional company and then get not only the net asset value but also cash in the future membership rights for whatever they might fetch. This propertyrights defect is intrinsic to democratic firms and cannot be remedied without destroying the democratic character of the firm. The membership rights in a democratic firm must join the other nonmarketable and inalienable human rights in the ignoble status of being "market imperfections."

\section{References}

Alchian, A., and H. Demsetz. 1972. Production, information costs, and economic organization. American Economic Review 62: 777-95.

Arrow, K. J. 1971. The firm in general equilibrium theory. In The corporate economy, ed. R. Marris and A. Woods. Cambridge, MA: Harvard University Press.

Arrow, K. J., and G. Debreu. 1954. Existence of an equilibrium for a competitive economy. Econometrica 22: 265-90.

Black, H. 1968. Black's law dictionary. St. Paul, MN: West.

Catlett, G., and N. Olson 1968. ARS No. 10: Accounting for goodwill. New York: American Institute of Certified Public Accountants.

Christ, C. F. 1975. The competitive market and optimal allocative efficiency. In Competing philosophies in American political economics, ed. J. Elliott and J. Cownie, 332-38. Santa Monica, CA: Goodyear.

Dow, G. 1993. Why capital hires labor: A bargaining perspective. American Economic Review 83 (1): 118-34. . 2003. Governing the firm: Workers' control in theory and practice. Cambridge, UK: Cambridge University Press.

Ellerman, D. 1972. Introduction to normative property theory. Review of Radical Political Economics 4 (2 Summer): 49-67.

- 1973. Capitalism and workers' self-management. In Workers' control: A reader on labor and social change, ed. G. Hunnius, D. Garson, and J. Case, 3-21. New York: Random House.

1982. Economics, accounting, and property theory. Lexington, MA: D. C. Heath.

. 1986. Horizon problems and property rights in labor-managed firms. Journal of Comparative Economics 10 (March 1986): 62-78.

. 1992. Property \& contract in economics: The case for economic democracy. Cambridge, MA: Blackwell. [Out-of-print with rights reverted to the author, so the full text is available at: www.ellerman.org.]

. 1995. Intellectual trespassing as a way of life: Essays in philosophy, economics, and mathematics. Lanham, MD: Rowman \& Littlefield.

Fama, E., and M. Jensen. 1996. Organizational forms and investment decisions. In The economic nature of the firm, 2nd ed., ed. L. Putterman and R. Kroszner, 336-44. Cambridge, UK: Cambridge University Press.

Furubotn, E., and S. Pejovich. 1970. Property rights and the behavior of the firm in a socialist state: The example of Yugoslavia. Zeitschrift fur Nationalokonomie 30 (3-4): 431-54.

- eds. 1974. The economics of property rights. Cambridge, MA: Ballinger.

Goodwyn, L. 1978. The populist moment. New York: Oxford University Press.

Grob, G. 1969. Workers and utopia. Chicago: Quadrangle.

Haavelmo, T. 1960. A study in the theory of investment. Chicago: University of Chicago Press. 
Hansmann, H. 1990. Ownership of the firm. In Corporate law and economic analysis, ed. L. A. Bebchuk, 281-313. Cambridge, UK: Cambridge University Press.

. 1996. The ownership of enterprise. Cambridge: Harvard University Press.

Hart, O. 1995. Firms, contracts, and financial structure. Oxford, UK: Clarendon.

Hart, O., and J. Moore. 1990. Property rights and the nature of the firm. Journal of Political Economy 98: $1119-59$.

Hirshleifer, J. 1970. Investment, interest, and capital. Upper Saddle River, NJ: Prentice Hall.

Holmstrom, B., and J. Tirole. 1989. The theory of the firm. In Handbook of industrial organization, vol. 1, ed. R. Schmalensee and R. Willig, 63-133. Amsterdam, North-Holland: Elsevier.

Keynes, J. M. 1936. The general theory of employment, interest, and money. New York: Harcourt, Brace \& World. Lasch, C. 1991. The true and only heaven. New York: Norton.

Maitland, F. W. 1960. Frederic William Maitland: Historian, ed. R. L. Schuyler. Berkeley: University of California Press.

Marx, K. [1867] 1967. Capital: A critique of political economy, vol. 1, trans. S. Moore and E. Aveling. New York: International Publishers.

Menger, A. 1899. The right to the whole produce of labour: The origin and development of the theory of labour's claim to the whole product of industry, trans. M. E. Tanner, intro. H. S. Foxwell. London: Macmillan and Co. (repr. Augustus Kelley).

Miller, M. H., and F. Modigliani. 1961. Dividend policy, growth, and the valuation of shares. The Journal of Business 34 (October): 411-33.

Montias, J. M. 1976. The structure of economic systems. New Haven, CT: Yale University Press.

Putterman, L. 1996. Ownership and the nature of the firm. In The economic nature of the firm, ed. L. Putterman and R. Kroszner, 361-69. Cambridge, UK: Cambridge University Press.

Putterman, L., and R. S. Kroszner, eds. 1996. The economic nature of the firm, 2nd ed. Cambridge, UK: Cambridge University Press.

Samuelson, P. A. 1976. Economics, 10th ed. New York: McGraw-Hill.

Vanek, J. 1970. The general theory of labor-managed market economies. Ithaca, NY: Cornell University Press. . 1975. The basic theory of financing of participatory firms. In Self-management, ed. J. Vanek, 445-55. New York: Penguin.

. 1977. The labor-managed economy. Ithaca, NY: Cornell University Press.

Varian, H. 1984. Microeconomic analysis, 2nd ed. New York: W. W. Norton.

von Gierke, O. 1958. Political theories of the middle age, trans. F. W. Maitland. Boston: Beacon.

David Ellerman has worked for more than three decades on the labor theory of property and the legal structure of worker cooperatives, from a 1972 RRPE article through ten years with the Industrial Cooperative Association to the present RRPE article and other materials (www.ellerman.org). In the meantime, he spent ten years at the World Bank, highlighted by three years as advisor and speech writer for Chief Economist Joseph Stiglitz. He is currently a visiting scholar at the University of California at Riverside and has just published a book, Helping People Help Themselves (2005), that gives an indirect and autonomy-respecting approach to development assistance. 